\title{
Antioxidant effects of curcumin in spinal cord injury in rats
}

\author{
Sıçanlarda spinal kord yaralanmsında curcuminin antioksidan etkileri
}

\author{
Havva ŞAHIN KAVAKLI, ${ }^{1}$ Cemile KOCA, ${ }^{2}$ Özlem ALICI ${ }^{3}$
}

\section{BACKGROUND}

This experimental study was performed to investigate the benefit of curcumin via its antioxidant effect on spinal cord injury (SCI) in rats.

\section{METHODS}

Twenty-four adult Wistar albino rats were randomized into three groups. SCI was performed by the weight-drop model. Group 1 underwent laminectomy followed by SCI and received no medication. Group 2 underwent laminectomy followed by SCI and received curcumin $(200 \mathrm{mg} /$ $\mathrm{kg}$ /day orally). Group 3 underwent laminectomy followed by $\mathrm{SCI}$ and received methylprednisolone $(30 \mathrm{mg} / \mathrm{kg}$ intraperitoneally). Twenty-four hours later, blood samples were obtained from all rats; serum superoxide dismutase (SOD) and malondialdehyde (MDA) levels were determined, and the obtained results were compared.

\section{RESULTS}

SOD level in the curcumin group was higher than in the control group $(\mathrm{p}<0.000)$ and methylprednisolone group $(p<0.012)$. MDA level in the curcumin group was lower than in the control group $(p<0.042)$. Similarly, the MDA level in the methylprednisolone group was lower than in the control group $(\mathrm{p}<0.001)$.

\section{CONCLUSION}

The results of the present study show that curcumin effectively protects the spinal cord tissues against oxidative damage.

Key Words: Antioxidant; curcumin; malondialdehyde; spinal cord injury; superoxide dismutase.

\section{$\boldsymbol{A M} \boldsymbol{A C ̧}$}

Bu deneysel çalışma, sıçanlarda spinal kord yaralanmasında curcuminin antioksidan etki yoluyla faydasını araştırmak için yapıldı.

\section{GEREÇ VE YÖNTEM}

Yirmi dört adet Wistar albino sıçan 3 gruba randomize edildi. Spinal kord yaralanması ağırlık düşürme modeliyle gerçekleştirildi. Grup 1'e laminektomi ardından spinal kord yaralanması uygulandı ve herhangi bir tedavi verilmedi. Grup 2'ye laminektomi ardından spinal kord yaralanması uygulandı ve curcumin verildi (200 mg/kg/gün ağızdan). Grup 3 'e laminektomi ardından spinal kord yaralanması uygulandi ve metilprednizolon verildi (30 mg/kg periton içine), 24 saat sonra tüm sıçanlardan kan örnekleri alındı, sonra serum süperoksit dismutaz (SOD) ve malondialdehit (MDA) düzeyleri belirlendi ve elde edilen sonuçlar karşılaştırıldı.

\section{BULGULAR}

Curcumin grubunda SOD düzeyi kontrol ve metilprednizolon grubundan daha yüksekti $(p<0,001$ ve $p<0,012)$. Curcumin grubunda MDA düzeyi kontrol grubundan daha düşüktü $(\mathrm{p}<0,042)$. Benzer şekilde metilprednizolon grubunda MDA düzeyi kontrol grubundan daha düşüktü $(\mathrm{p}<0,001)$.

\section{SONUÇ}

$\mathrm{Bu}$ çalışmanın sonuçları curcuminin etkin biçimde oksidatif hasara karşı spinal kord dokularını koruduğunu gösterir.

Anahtar Sözcükler: Antioksidan; curcumin; malondialdehit; spinal kord yaralanması; süperoksit dismutaz.

\footnotetext{
${ }^{1}$ Department af Emergency Medicine, Ankara Ataturk Training and Research Hospital, Ankara; ${ }^{2}$ Department of Biochemistry, Fatih University Faculty of Medicine, Ankara; ${ }^{3}$ Department of Infectious Diseases and Clinical Bacteriology, Medical Park Hospital, Istanbul, Turkey.
}
${ }^{1}$ Ankara Atatürk Eğitim ve Araştırma Hastanesi, Acil Tıp Kliniği, Ankara; ${ }^{2}$ Fatih Üniversitesi Tıp Fakültesi, Biyokimya Bölümü, Ankara; ${ }^{3}$ Medikal Park Hastanesi, Enfeksiyon Hastalıkları ve Klinik Mikrobiyoloji Bölümü, İstanbul.


Spinal cord injury (SCI) is one of the most devastating conditions that affects both patients and society. ${ }^{[1,2]}$ SCI mainly occurs via two mechanisms as primary and secondary injury. Secondary injury after the primary impact includes different pathophysiological and biochemical events. ${ }^{[3-13]}$ Oxygen-derived free radicals have been implicated in the pathogenesis of spinal cord neuronal injury after trauma. Decreasing the level of oxidative stress minimizes the secondary destruction effect after traumatic injury. ${ }^{[10]}$

Methylprednisolone is a pharmacological agent that has clinically proven useful effects on functional recovery following $\mathrm{SCI}^{[3,4]}$ Additionally, curcumin has been shown to have various clinical and experimental beneficial effects. The protective effect of curcumin on induced tissue damage due to free radicals has been observed previously in a number of experimental models. ${ }^{[14-17]}$ Previous studies have demonstrated that curcumin also exhibits an antioxidant property as well as anti-inflammatory, immunomodulatory, anticancer, and antiangiogenic properties via its pleiotropic effects on genes and cell-signaling pathways at multiple levels. ${ }^{[18]}$ A recent experimental SCI study showed that curcumin blocked apoptosis and neuron loss, restrained astrocyte activation, and significantly improved neurologic deficit. By down-regulating glial fibrillary acidic protein expression, curcumin seems to diminish astrocyte reactivation, which may be useful for neuronal survival. ${ }^{[19]}$

The objective of our study was to determine the antioxidant effects of curcumin in rats with SCI. We also aimed to compare the effects of curcumin with those of methylprednisolone.

\section{MATERIALS AND METHODS}

Twenty-four male Wistar albino rats (250-270 g) were used in the study. All the protocols were approved by the institutional animal ethics committee. The rats in each group were kept in separate cages in rooms with controlled light and temperature and were fed standard chow and water ad libitum. The animals were anesthetized by an intraperitoneal injection of 10 mg/kg xylazine (Rompun, Bayer Turk Kimya Sanayii Limited Sirketi, Istanbul, Turkey) and $50 \mathrm{mg} / \mathrm{kg}$ ketamine hydrochloride (Ketalar, Pfizer Ilacları Limited Sirketi, Istanbul, Turkey). Rats were positioned on a thermistor-controlled heating pad in the prone position and a rectal probe was inserted. Surgical procedures were performed under sterile conditions with the assistance of a surgical microscope. Following T5-12 midline skin incision and paravertebral muscle dissection, spinous processes and laminar arcs of T7-10 were removed. The dura was left intact. Weight-drop model was performed for SCI..$^{[4,20,21]}$ The animals were subjected to an impact of $50 \mathrm{~g} / \mathrm{cm}$ to the dorsal surface of the spinal cord. The force was applied via a stainless steel rod ( $3 \mathrm{~mm}$ diameter tip, weight $5 \mathrm{~g}$ ) that was rounded at the surface. The rod was dropped vertically through a $10 \mathrm{~cm}$ guide tube that was positioned perpendicular to the center of the spinal cord. Afterwards, the muscles and the incision were sutured with 6-0 Vicryl (Vicryl, Ethicon, Johnson \& Johnson Intl, Lanneke Marelaan, Belgium).

The rats were randomized into three groups of 8 rats each. Group 1 underwent laminectomy followed by SCI and did not receive medication. Group 2 underwent laminectomy followed by SCI and received curcumin $200 \mathrm{mg} / \mathrm{kg} /$ day orally. ${ }^{[22-24]}$ Group 3 underwent laminectomy followed by SCI and received methylprednisolone (Prednol-L, Mustafa Nevzat Ilac Sanayi Anonim Sirketi, Istanbul, Turkey) intraperitoneally at a single dose of $30 \mathrm{mg} / \mathrm{kg}$. Following the surgical procedure, the rats were placed in a warming chamber and their body temperatures were maintained at approximately $37^{\circ} \mathrm{C}$ until they were completely awake. In the early postoperative period, the rats received $3 \mathrm{ml}$ of saline intraperitoneally to compensate for the blood loss during the surgical procedure, while the water intake was limited.

\section{Biochemical Analysis}

Twenty-four hours later, blood samples were obtained from all rats. The blood samples were immediately frozen and stored in a $-20^{\circ} \mathrm{C}$ freezer for assays of malondialdehyde (MDA) and superoxide dismutase (SOD) levels. SOD activity was assayed according to the method of Sun et al. ${ }^{[25]}$ Blood samples were mixed with the same ratio of chloroform and ethanol mixture $(3 / 5 \mathrm{v} / \mathrm{v})$. This mixture was then centrifuged at $5000 \times$ $\mathrm{g}$ for 2 hours (h). This assay for SOD activity involves xanthine oxidase used as superoxide, and the results were expressed as unit per ml. One unit of SOD is defined as the amount of protein that inhibits the rate of nitroblue tetrazolium reduction by $50 \%$.

The levels of the end product of lipid peroxidation, serum MDA, were determined by thiobarbituric acid (TBA) test in which 1,1,3,3-tetraethoxypropane was used as standard. The TBA test is based upon the principle of calorimetrically measured concentration of the pink product at $535 \mathrm{~nm}$ wavelength, which is formed as a result of the reaction of TBA with lipid peroxides (MDA), which are called TBA reactive substances. The results were expressed as nmol MDA/ml. ${ }^{[26]}$

\section{Statistical Analysis}

For statistical evaluation, we used the software package SPSS 15.0, and probability value of less than 0.05 was accepted as statistically significant. As the data were normally distributed and independent, statistical analysis was performed using analysis of variance (ANOVA) followed by Tukey test when com- 


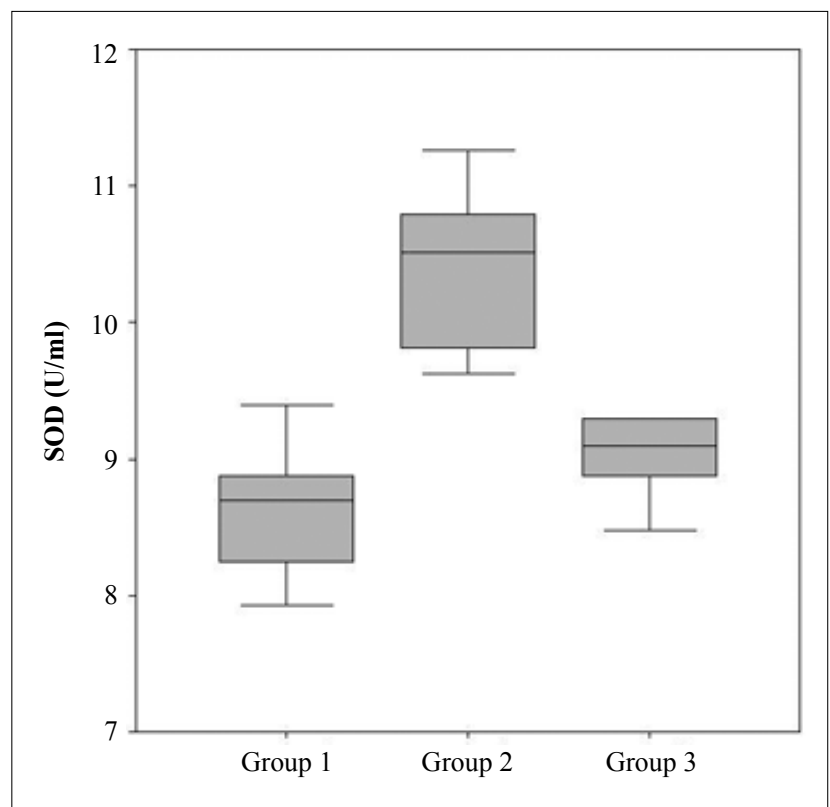

Fig. 1. SOD level differences between groups.

paring groups. The results are given as the mean \pm standard deviation of the mean (SD).

\section{RESULTS}

SOD level in the curcumin group was higher than in the control group $(\mathrm{p}<0.001)$ and methylprednisolone group $(\mathrm{p}<0.012)$ (Fig. 1). The MDA level in the curcumin group was lower than in the control group $(p<0.042)$. Similarly, the MDA level in the methylprednisolone group was lower than in the control group $(\mathrm{p}<0.001)$ (Fig. 2).

For all groups, SOD and MDA levels are shown as mean \pm SD in Table 1 .

\section{DISCUSSION}

In our study, serum SOD levels were found to be significantly increased in the curcumin group when compared to the control group and methylprednisolone group. Furthermore, curcumin reduced serum MDA, which is an indicator of lipid peroxidation, with respect to the control group. Spinal cord trauma results in a rapid and extensive oxidative stress. It has long been established that oxidative stress plays a critical role in the pathophysiology of $\mathrm{SCI}^{[27-29]}$ Oxi-

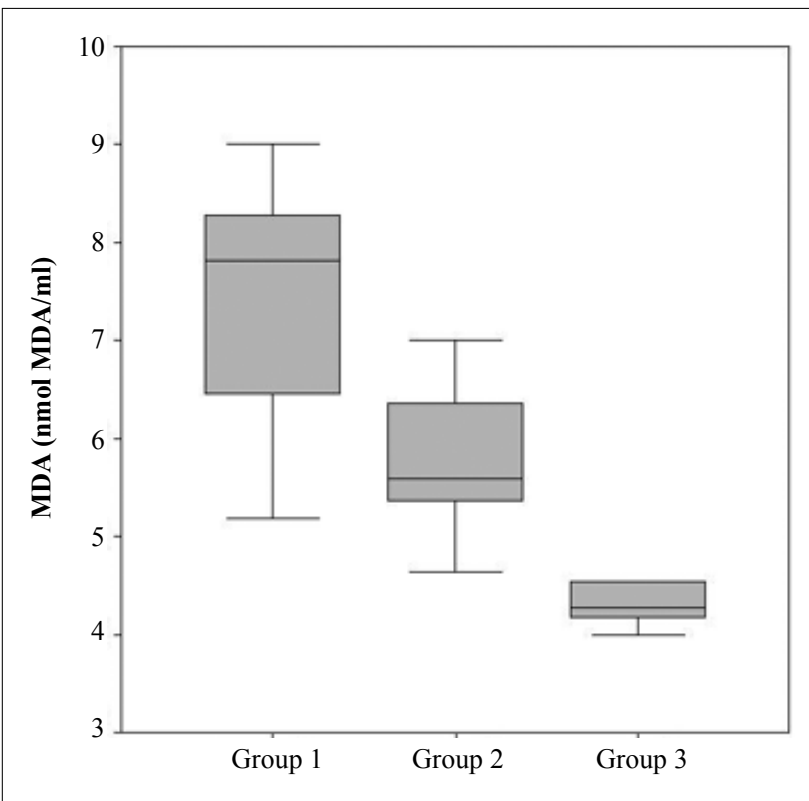

Fig. 2. MDA level differences between groups.

dative stress can result from increased reactive oxygen species (ROS) production, and/or from decreased ROS scavenging capability. The cells' natural protective system against the devastating actions of ROS includes the protective enzymes including SOD and other antioxidants. It is believed to play important roles in reversing the pathological damage caused by SCI. Prime targets of ROS attack are the polyunsaturated fatty acids (PUFA) in the membrane lipids causing lipid peroxidation, which may lead to disorganization of cell structure and function. Further, decomposition of peroxidized lipids yields a wide variety of end products, including MDA. ${ }^{[30]}$ ROS are cleared via enzymatic, including SOD, and nonenzymatic antioxidative mechanisms. SOD is a protective enzyme that can efficiently and specifically scavenge the superoxide radical by catalyzing its dismutation to hydrogen peroxide and oxygen. Lipid peroxidation is the main cause of the further secondary damage that starts after mechanical destruction of tissues.$^{[3,4,11,31]}$ Lipid peroxidation products increase immediately after SCI, and the peak concentrations of ROS and nitrogen species occur within the first 24 hours. ${ }^{[4]}$ In this study, we determined oxidative injury in the spinal cord during

Table 1. SOD and MDA levels (mean \pm SD)

\begin{tabular}{lcc}
\hline & $\begin{array}{c}\text { SOD } \\
(\mathrm{U} / \mathrm{ml})\end{array}$ & $\begin{array}{c}\text { MDA } \\
(\mathrm{nmol} \mathrm{MDA} / \mathrm{ml})\end{array}$ \\
\hline Group 1 (control) & $8.61 \pm 0.50$ & $7.35 \pm 1.43^{\mathrm{b}}$ \\
Group 2 (curcumin) & $10.42 \pm 0.61^{\mathrm{a}}$ & $5.75 \pm 0.82$ \\
Group 3 (methylprednisolone) & $9.21 \pm 0.69$ & $4.49 \pm 0.57$ \\
\hline p values & & \\
${ }^{a}$ Group 1 and 2 $\mathrm{p}<0.000$ & bGroup 1 and 2 $\mathrm{p}<0.042$ & \\
Group 2 and 3 $\mathrm{p}<0.012 \quad$ Group 1 and 3 $\mathrm{p}<0.001$ & &
\end{tabular}


SCI by measuring MDA concentration, since it is the end product of lipid peroxidation. MDA is the breakdown product of the major chain reactions leading to the oxidation of PUFA, and thus, serves as a reliable marker of oxidative stress-mediated lipid peroxidation. ${ }^{[32]}$ Measurement of SOD provides information about the antioxidant capacity of the organism. ${ }^{[33]} \mathrm{Al}-$ though it is difficult to limit the primary injury, there is increasing evidence of the possibility of lowering the impact of the secondary injury, using pharmacological strategies ${ }^{[3,34-36]}$ Antioxidant treatments decrease damage due to SCI by reducing oxidative stress. ${ }^{[4]}$ Recent studies have shown that curcumin has neuroprotective properties. ${ }^{[37-41]}$ In this study, we aimed to investigate the effect of curcumin treatment in SCI on the oxidant and anti-oxidant enzyme systems. Curcumin is a well-known neuroprotective agent. It is a phytochemical compound extracted from the rhizome of $\mathrm{C}$. longa Linn. Curcumin is one of the most potent and specific antioxidants for hydroxyl radicals, and it acts as a potent scavenger of free radicals. ${ }^{[42]}$ Considering these functions of curcumin, we attempted to use curcumin as a potential protector of neurons against SCI. Curcumin is easily available, inexpensive, and has proven to be non-toxic even when administered at high doses. ${ }^{[43]}$ Various studies have clearly pointed out that methylprednisolone enhances functional recovery and induces regenerative responses after SCI in humans and experimental animals, ${ }^{[2,4]}$ but it is not effective enough and is sometimes associated with some side effects. Since methylprednisolone is the only agent shown to have beneficial effects after SCI, it was used in this study to compare the treatment results with curcumin. Our study on the oxidative stress showed that curcumin possesses significant antioxidant activity by increasing SOD and reducing MDA, which is an index of lipid peroxidation that reflects the present oxidative status. Therefore, we consider that curcumin may be used in combination with high-dose methylprednisolone in SCI. These results clearly suggest the potential effect of curcumin to reduce the damage due to SCI injury in rats.

\section{REFERENCES}

1. Ibarra A, Martiñón S. Pharmacological approaches to induce neuroregeneration in spinal cord injury: an overview. Curr Drug Discov Technol 2009;6:82-90.

2. Xu WB, Lv G, Wang YF, Lu XH, Huang T, Zhu Y, et al. Combination of dexamethasone and aminoguanidine reduces secondary damage in compression spinal cord injury. Cell Mol Neurobiol 2009;29:683-9.

3. Hall ED, Springer JE. Neuroprotection and acute spinal cord injury: a reappraisal. NeuroRx 2004;1:80-100.

4. Yücel N, Cayli SR, Ateş O, Karadağ N, Firat S, Turköz Y. Evaluation of the neuroprotective effects of citicoline after experimental spinal cord injury: improved behavioral and neuroanatomical recovery. Neurochem Res 2006;31:767-75.

5. Guimarães JS, Freire MA, Lima RR, Souza-Rodrigues RD,
Costa AM, dos Santos CD, et al. Mechanisms of secondary degeneration in the central nervous system during acute neural disorders and white matter damage. Rev Neurol 2009;48:304-10. [Abstract]

6. Xiong Y, Hall ED. Pharmacological evidence for a role of peroxynitrite in the pathophysiology of spinal cord injury. Exp Neurol 2009;216:105-14.

7. Cayli SR, Kocak A, Yilmaz U, Tekiner A, Erbil M, Ozturk C, et al. Effect of combined treatment with melatonin and methylprednisolone on neurological recovery after experimental spinal cord injury. Eur Spine J 2004;13:724-32.

8. Mautes AE, Bergeron M, Sharp FR, Panter SS, Weinzierl M, Guenther K, et al. Sustained induction of heme oxygenase-1 in the traumatized spinal cord. Exp Neurol 2000;166:254-65.

9. Hamann K, Durkes A, Ouyang H, Uchida K, Pond A, Shi R. Critical role of acrolein in secondary injury following ex vivo spinal cord trauma. J Neurochem 2008;107:712-21.

10. Yazihan N, Uzuner K, Salman B, Vural M, Koken T, Arslantas A. Erythropoietin improves oxidative stress following spinal cord trauma in rats. Injury 2008;39:1408-13.

11. Michael-Titus AT. Omega-3 fatty acids and neurological injury. Prostaglandins Leukot Essent Fatty Acids 2007;77:295300 .

12. Faden AI. Pharmacological treatment of central nervous system trauma. Pharmacol Toxicol 1996;78:12-7.

13. Xiong Y, Singh IN, Hall ED. Tempol protection of spinal cord mitochondria from peroxynitrite-induced oxidative damage. Free Radic Res 2009;43:604-12.

14. Zheng YY, Yu LS, Zhang YG, Ye GH, Yi JP. Effects of curcumin on malondialdehyde and c-fos protein in hypoxia ischemia brain tissue in rats. Fa Yi Xue Za Zhi 2009;25:6-8. [Abstract]

15. Ilbey YO, Ozbek E, Cekmen M, Simsek A, Otunctemur A, Somay A. Protective effect of curcumin in cisplatin-induced oxidative injury in rat testis: mitogen-activated protein kinase and nuclear factor-kappa B signaling pathways. Hum Reprod 2009;24:1717-25.

16. Nazam Ansari M, Bhandari U, Pillai KK. Protective role of curcumin in myocardial oxidative damage induced by isoproterenol in rats. Hum Exp Toxicol 2007;26:933-8.

17. Roselló DM, Balestrasse K, Coll C, Coll S, Tallis S, Gurni A, et al. Oxidative stress and hippocampus in a low-grade hepatic encephalopathy model: protective effects of curcumin. Hepatol Res 2008;38:1148-53.

18. Strimpakos AS, Sharma RA. Curcumin: preventive and therapeutic properties in laboratory studies and clinical trials. Antioxid Redox Signal 2008;10:511-45.

19. Lin MS, Lee YH, Chiu WT, Hung KS. Curcumin Provides Neuroprotection After Spinal Cord Injury. J Surg Res 2009 Aug 5. [Epub ahead of print]

20. Bilginer B, Onal MB, Narin F, Ustun H, Kilinc K, Akalan N. Antiapoptotic and neuroprotective effects of mycophenolate mofetil after acute spinal cord injury in young rats. Childs Nerv Syst 2009;25:1555-61.

21.Zeman RJ, Bauman WA, Wen X, Ouyang N, Etlinger JD, Cardozo CP. Improved functional recovery with oxandrolone after spinal cord injury in rats. Neuroreport 2009;20:864-8.

22. Bayrak O, Uz E, Bayrak R, Turgut F, Atmaca AF, Sahin S, et al. Curcumin protects against ischemia/reperfusion injury in rat kidneys. World J Urol 2008;26:285-91.

23. Reeta KH, Mehla J, Gupta YK. Curcumin is protective against phenytoin-induced cognitive impairment and oxidative stress in rats. Brain Res 2009;1301:52-60. 
24. Wan XH, Li YW, Luo XP. Curcumin attenuated the lipid peroxidation and apoptotic liver injury in copper-overloaded rats. Zhonghua Er Ke Za Zhi 2007;45:604-8.

25. Sun Y, Oberley LW, Li Y. A simple method for clinical assay of superoxide dismutase. Clin Chem 1988;34:497-500.

26. Yoshioka T, Kawada K, Shimada T, Mori M. Lipid peroxidation in maternal and cord blood and protective mechanism against activated-oxygen toxicity in the blood. Am J Obstet Gynecol 1979;135:372-6.

27. DeRuisseau LR, Recca DM, Mogle JA, Zoccolillo M, DeRuisseau KC. Metallothionein deficiency leads to soleus muscle contractile dysfunction following acute spinal cord injury in mice. Am J Physiol Regul Integr Comp Physiol 2009;297:R1795-802.

28. Savas M, Verit A, Ciftci H, Yeni E, Aktan E, Topal U, et al. Oxidative Stress in BPH. JNMA J Nepal Med Assoc 2009;48:41-5.

29. Christie SD, Comeau B, Myers T, Sadi D, Purdy M, Mendez I. Duration of lipid peroxidation after acute spinal cord injury in rats and the effect of methylprednisolone. Neurosurg Focus 2008;25:E5.

30. Ilhan A, Koltuksuz U, Ozen S, Uz E, Ciralik H, Akyol O. The effects of caffeic acid phenethyl ester (CAPE) on spinal cord ischemia/reperfusion injury in rabbits. Eur J Cardiothorac Surg 1999; 16:458-63.

31. Golding JD, Rigley MacDonald ST, Juurlink BH, Rosser $\mathrm{BW}$. The effect of glutamine on locomotor performance and skeletal muscle myosins following spinal cord injury in rats. J Appl Physiol 2006;101:1045-52.

32. Balci M, Namuslu M, Devrim E, Durak I. Effects of computer monitor-emitted radiation on oxidant/antioxidant balance in cornea and lens from rats. Mol Vis 2009;15:2521-5.

33. Rabus M, Demirbağ R, Sezen Y, Konukoğlu O, Yildiz A, Erel $\mathrm{O}$, et al. Plasma and tissue oxidative stress index in patients with rheumatic and degenerative heart valve disease.
Turk Kardiyol Dern Ars 2008;36:536-40.

34. Michael-Titus AT. Omega-3 fatty acids and neurological injury. Prostaglandins Leukot Essent Fatty Acids 2007;77:295300.

35. Hall ED. Pharmacological treatment of acute spinal cord injury: how do we build on past success? J Spinal Cord Med 2001;24:142-6.

36. Faden AI, Stoica B. Neuroprotection: challenges and opportunities. Arch Neurol 2007;64:794-800.

37. Yadav RS, Sankhwar ML, Shukla RK, Chandra R, Pant AB, Islam $\mathrm{F}$, et al. Attenuation of arsenic neurotoxicity by curcumin in rats. Toxicol Appl Pharmacol 2009;240:367-76.

38. Wang R, Li YB, Li YH, Xu Y, Wu HL, Li XJ. Curcumin protects against glutamate excitotoxicity in rat cerebral cortical neurons by increasing brain-derived neurotrophic factor level and activating TrkB. Brain Res 2008;1210:84-91.

39. Dutta K, Ghosh D, Basu A. Curcumin protects neuronal cells from Japanese encephalitis virus-mediated cell death and also inhibits infective viral particle formation by dysregulation of ubiquitin-proteasome system. J Neuroimmune Pharmacol 2009; 4:328-37.

40. Sethi P, Jyoti A, Hussain E, Sharma D. Curcumin attenuates aluminium-induced functional neurotoxicity in rats. Pharmacol Biochem Behav 2009;93:31-9.

41. Zhao J, Zhao Y, Zheng W, Lu Y, Feng G, Yu S. Neuroprotective effect of curcumin on transient focal cerebral ischemia in rats. Brain Res 2008;1229:224-32.

42. Bas M, Tugcu V, Kemahli E, Ozbek E, Uhri M, Altug T, et al. Curcumin prevents shock-wave lithotripsy-induced renal injury through inhibition of nuclear factor kappa-B and inducible nitric oxide synthase activity in rats. Urol Res 2009;37:159-64.

43. Alamdari N, O’Neal P, Hasselgren PO. Curcumin and muscle wasting: a new role for an old drug? Nutrition 2009;25:1259. 